\title{
The Effect of Chironomid Larvae on Nitrogen Cycling and Microbial Communities in Soft Sediments
}

\author{
Aurelija Samuiloviene ${ }^{1}$, Marco Bartoli ${ }^{1,2}{ }^{(D)}$, Stefano Bonaglia 1,3,4 ${ }^{(}$, Ulisse Cardini ${ }^{1,5}$, \\ Irma Vybernaite-Lubiene ${ }^{1}$, Ugo Marzocchi 1,5 ${ }^{\mathbb{D}}$, Jolita Petkuviene ${ }^{1}$, Tobia Politi ${ }^{1}$, \\ Anastasija Zaiko ${ }^{1,6,7}$ and Mindaugas Zilius $1,8, * \mathbb{D}$ \\ 1 Marine Research Institute, Klaipeda University, 92294 Klaipeda, Lithuania; \\ aurelija.samuiloviene@jmtc.ku.lt (A.S.); irma.lubiene@apc.ku.lt (I.V.-L.); jolita.petkuviene@apc.ku.lt (J.P.); \\ tobia.politi@jmtc.ku.lt (T.P.) \\ 2 Department of Chemistry, Life science and Environmental Sustainability, Parma University, 43124 Parma, \\ Italy; marco.bartoli@unipr.it \\ 3 Department of Ecology, Environment and Plant Sciences, Stockholm University, 10691 Stockholm, Sweden; \\ stefano.bonaglia@su.se \\ 4 Department of Biology, University of Southern Denmark, 5230 Odense, Denmark \\ 5 Integrative Marine Ecology Department, Stazione Zoologica Anton Dohrn, National Institute of Marine \\ Biology, Ecology and Biotechnology, 8012 Napoli, Italy; ulisse.cardini@szn.it (U.C.); \\ ugomar@bios.au.dk (U.M.) \\ 6 Coastal and Freshwater Group, Cawthron Institute, 7042 Nelson, New Zealand; \\ anastasija.zaiko@cawthron.org.nz \\ 7 Institute of Marine Science, University of Auckland, 0941 Warkworth, New Zealand \\ 8 Department of Life Science and Biotechnology, Ferrara University, 44121 Ferrara, Italy \\ * Correspondence: mindaugas.zilius@jmtc.ku.lt
}

Received: 10 August 2019; Accepted: 11 September 2019; Published: 16 September 2019 updates

\begin{abstract}
The combination of biogeochemical methods and molecular techniques has the potential to uncover the black-box of the nitrogen $(\mathrm{N})$ cycle in bioturbated sediments. Advanced biogeochemical methods allow the quantification of the process rates of different microbial processes, whereas molecular tools allow the analysis of microbial diversity (16S rRNA metabarcoding) and activity (marker genes and transcripts) in biogeochemical hot-spots such as the burrow wall or macrofauna guts. By combining biogeochemical and molecular techniques, we analyzed the role of tube-dwelling Chironomus plumosus (Insecta, Diptera) larvae on nitrification and nitrate reduction processes in a laboratory experiment with reconstructed sediments. We hypothesized that chironomid larvae stimulate these processes and host bacteria actively involved in N-cycling. Our results suggest that chironomid larvae significantly enhance the recycling of ammonium $\left(80.5 \pm 48.7 \mu \mathrm{mol} \mathrm{m}^{-2} \mathrm{~h}^{-1}\right)$ and the production of dinitrogen $\left(420.2 \pm 21.4 \mu \mathrm{mol} \mathrm{m}^{-2} \mathrm{~h}^{-1}\right)$ via coupled nitrification-denitrification and the consumption of water column nitrates. Besides creating oxygen microniches in ammonium-rich subsurface sediments via burrow digging and ventilation, chironomid larvae serve as hot-spots of microbial communities involved in N-cycling. The quantification of functional genes showed a significantly higher potential for microbial denitrification and nitrate ammonification in larvae as compared to surrounding sediments. Future studies may further scrutinize $\mathrm{N}$ transformation rates associated with intimate macrofaunal-bacteria associations.
\end{abstract}

Keywords: chironomid larvae; nitrogen; microbial community; 16S rRNA; functional genes; denitrification; sediment 


\section{Introduction}

Shallow estuarine systems are efficient coastal filters and biogeochemical reactors which regulate organic matter and nutrient loads from land to the sea [1,2]. Their elevated retention of organic sediment fuels high rates of benthic heterotrophic activity and primary production [3]. Such energy and matter flows have positive feedbacks for benthic biodiversity and for the network of ecological interactions that connect physical and biological compartments [3,4]. Thus, estuarine nitrogen $(\mathrm{N})$ cycling is a paradigmatic example of a set of biogeochemical transformations connecting micro- and macro-organisms, modulated by physical environments and undergoing complex regulation and feedbacks [5-7]. Within the estuarine $\mathrm{N}$ cycle, permanent $\mathrm{N}$ removal via dissimilative processes such as denitrification is of particular interest, as well as undesired dissimilative nitrate reduction to ammonium (DNRA)-N recycling, which is favoured under eutrophic conditions $[8,9]$. Processes leading to permanent $\mathrm{N}$ removal counteract the excessive loads of reactive $\mathrm{N}$ to coastal areas, resulting from anthropogenic activities such as agriculture and animal farming and inducing eutrophication, loss of biodiversity and the deterioration of ecosystem health [10,11].

Microbially-mediated $\mathrm{N}$ transformations in estuarine sediments are supported and stimulated by a range of macrofauna-related processes, collectively defined as bioturbation $[3,12,13]$. The multiple paths by which metabolic or feeding strategies and behavioural features of macrofauna affect the physical and biological environment and $\mathrm{N}$-cycling have been scrutinized in many experimental studies. These demonstrated that macrofauna may directly alter inorganic $\mathrm{N}$ concentrations as well as the quality and quantity of organic $\mathrm{N}$ via respiration, excretion and biodeposition activities [14-21]. Biodeposits from filter-feeding macrofauna, for example, may increase denitrification and ammonification rates [19,22]. Macrofauna are demonstrated to also produce indirect effects on $\mathrm{N}$ biogeochemistry via sediment reworking and burrow construction, ventilation or bioirrigation, which may stimulate coupled nitrification-denitrification $[14,15,23,24]$.

Therefore, being involved in N-cycling, macrofauna may facilitate the growth of primary producers or smooth their competition with bacteria for $\mathrm{N}$, resulting in simultaneous high uptake and high loss via denitrification $[7,25,26]$. Macrofauna may also locally affect microbial communities, creating specific niches such as shallow or deep burrow lining, where peculiar microbiomes develop along the chemical gradients $[17,20,27]$. Fascinating but less explored is the role of macrofauna as microbial community elevators or transporters, as macrofauna continuously migrate vertically and horizontally across sediments, exposing their associated microbiome to different chemical gradients (e.g., from oxygen $\left(\mathrm{O}_{2}\right)$ and nitrate $\left(\mathrm{NO}_{3}{ }^{-}\right)$-rich to anoxic, ammonium $\left(\mathrm{NH}_{4}{ }^{+}\right)$-rich). Even less is known about microbial activities occurring within the guts, gills or intestines of macrofauna [28,29]. Substantial densities of symbiotic microbes (e.g., N-fixers, sulphide oxidizers) were detected, for example, in the gills of lucinid bivalves [30]. Even though intimate microbe-macrofauna interactions are likely widespread, they are largely understudied due to methodological limitations or the oversimplification of experimental approaches. Therefore, the cumulative effects of macrofauna and their associated microbiomes are rarely accounted for in biogeochemical studies, and their actual magnitude may be underestimated when assessing ecosystem-wide processes.

The advances of in situ and laboratory approaches based on the use of isotopic tracers have allowed more accurate quantitative assessment of multiple microbial $\mathrm{N}$ transformations and their regulation, including ammonification, nitrification and nitrate reduction processes [7-9,16,21]. Integrating biogeochemical approaches with novel molecular tools (such as the metabarcoding of microbial biodiversity or quantification of target functional genes) enables the detailed exploration of macrofaunal-bacterial interactions and of their wider role in benthic ecosystem functioning [18,20,29].

In this study, we analysed the effects of sediment-dwelling Chironomus plumosus (Insecta, Diptera) larvae on benthic $\mathrm{N}$ transformations combining biogeochemical and functional genomic measurements under controlled conditions. We targeted chironomid larvae-an understudied group compared to other macrofauna-for multiple reasons. They may attain large densities and dominate in organic-rich, chemically reduced sediments, where they may create steep redox gradients across 
their burrows [12]. They are suspension feeders and pump large volumes of $\mathrm{O}_{2}$ and $\mathrm{NO}_{3}{ }^{-}$-rich water into sediments [31]. Therefore, we hypothesized a substantial stimulation of $\mathrm{N}$-cycling in sediments inhabited by chironomid larvae, as they may alter the sediment's physical structure and host bacteria that catalyse $\mathrm{N}$ transformations. To test this hypothesis, we measured inorganic $\mathrm{N}$ fluxes in bioturbated sediments in combination with the $16 \mathrm{~S}$ rRNA metabarcoding of bacterial communities isolated from (1) subsurface, anoxic sediments, (2) burrow wall sediments, and (3) chironomid larvae. We then quantified the representative marker genes involved in $\mathrm{N}$-cycling and their transcripts to better understand whether chironomid larvae and their associated microbiome may contribute to nitrification and/or to $\mathrm{NO}_{3}{ }^{-}$reduction.

\section{Materials and Methods}

\subsection{Experimental Setup}

In July 2018, muddy sediments with high organic carbon and total $\mathrm{N}$ contents $(12 \%$ and $1.8 \%$, respectively; [2]), water, and chironomid larvae (C. plumosus) were collected in the Lithuanian part of the Curonian Lagoon $\left(55^{\circ} 17^{\prime} 51.7^{\prime \prime} \mathrm{N}, 21^{\circ} 00^{\prime} 36.0^{\prime \prime} \mathrm{E}\right)$ at a water depth of $3 \mathrm{~m}$. In the laboratory, approximately $15 \mathrm{~L}$ of sediment was sieved through a $0.5 \mathrm{~mm}$ mesh to remove large debris, chironomid larvae and other occasional macrofauna, and gently mixed to a slurry. The homogenized sediment (median grain size $=0.032 \mu \mathrm{m}$ ) was transferred into 10 bottom-capped Plexiglass liners (height $=30 \mathrm{~cm}$, inner diameter $=8 \mathrm{~cm}$ ) to reconstruct a $10 \mathrm{~cm}$ sediment layer in each microcosm. Thereafter, all microcosms were carefully filled with unfiltered water from the sampling site.

Two treatments (five replicates each) were applied to the microcosm cores: sediments without macrofauna (control) and sediments with nine added chironomid larvae per core (corresponding to 1800 ind. $\mathrm{m}^{-2}$ ). All chironomid larvae added to the cores immediately burrowed in the sediment down to $3-5 \mathrm{~cm}$ depth. In each core, a magnetic bar was fixed $10 \mathrm{~cm}$ above the sediment surface to stir the water while avoiding sediment resuspension. Then, all the cores were submerged into a $200 \mathrm{~L}$ tank, filled with aerated and well-mixed lagoon water (salinity $=0.2, \mathrm{pH}=8.3$, dissolved inorganic $\mathrm{N}$ conc. $\left.\sim 2 \mu \mathrm{mol} \mathrm{L}{ }^{-1}\right)$ maintained at ambient temperature $\left(16 \pm 0.2^{\circ} \mathrm{C}\right)$. The tank was equipped with two central magnets rotating at $40 \mathrm{rpm}$, driving the magnet bars inside the cores. Thus, water exchange with the tank was ensured to avoid water column stratification inside the cores and regulate oxygenation. The cores were pre-incubated in the dark for 14 days to attain (1) stable vertical and horizontal chemical gradients after sediment sieving and homogenisation and chironomid larvae addition, and (2) stable bacterial communities within the sediment and along the burrows' walls [32]. During the pre-incubation period, all microcosms were regularly checked for the development of light brown halos along chironomid larvae burrows. About $30 \%$ of the tank water was renewed every 2 days to maintain suspended matter, nutrient concentrations and chemical gradients across the sediment-water interface close to in situ conditions. A scheme of the experimental set up is provided in Figure 1.

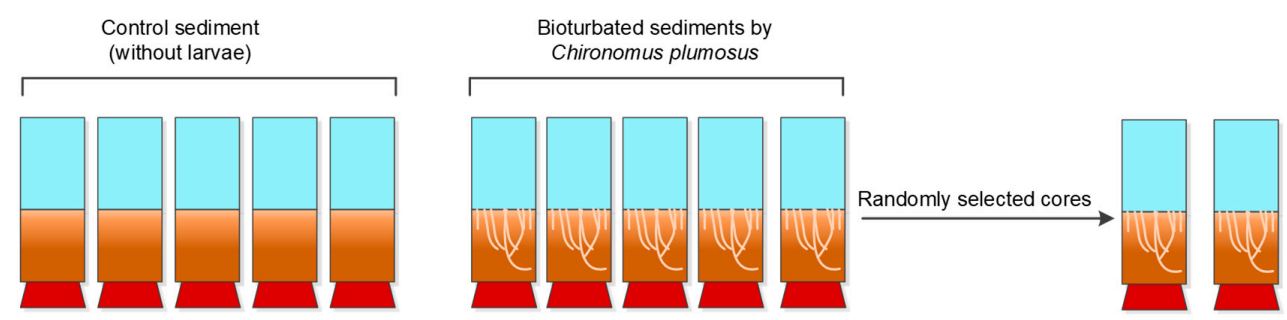

BIOGEOCHEMICAL MEASUREMENTS

- Net fluxes of gas $\left(\mathrm{O}_{2}, \mathrm{~N}_{2}, \mathrm{~N}_{2} \mathrm{O}\right)$

- Net fluxes of nitrogen $\left(\mathrm{NH}_{4}^{+}, \mathrm{NO}_{2}{ }^{-}, \mathrm{NO}_{3}{ }^{-}\right)$
MOLECULAR ANALYSIS

- Functional genes (amoA, nirS/K, nrfA )

- 16S rRNA

Figure 1. Scheme of the experimental set up. 


\subsection{Benthic Flux Measurement}

After 14 days of pre-incubation, benthic fluxes of dissolved gas $\left(\mathrm{O}_{2}, \mathrm{~N}_{2}, \mathrm{~N}_{2} \mathrm{O}\right)$ and inorganic $\mathrm{N}\left(\mathrm{NH}_{4}{ }^{+}, \mathrm{NO}_{2}{ }^{-}\right.$and $\left.\mathrm{NO}_{3}{ }^{-}\right)$were measured in all microcosms during $5 \mathrm{~h}$ incubation in dark [33]. Measurements were taken through a gas-tight top lid equipped with an optical sensor spots (PyroScience $\mathrm{GmbH}$, Aachen, Germany) and a sampling port. The incubation was restricted to $5 \mathrm{~h}$ to keep oxygen within $20-30 \%$ of the initial concentration. At the beginning and at the end of the incubation, $40 \mathrm{~mL}$ water samples were collected, with two aliquots immediately transferred into $12 \mathrm{~mL}$ exetainers (Labco Limited, Lampeter, UK) and fixed with $7 \mathrm{M} \mathrm{ZnCl}_{2}$ for $\mathrm{O}_{2}, \mathrm{~N}_{2}$, and $\mathrm{N}_{2} \mathrm{O}$ measurements. A $10 \mathrm{~mL}$ aliquot was filtered (Frisanette GF/F filters), transferred into a plastic test tube and frozen immediately $\left(-20^{\circ} \mathrm{C}\right)$ for later inorganic $\mathrm{N}$ analyses. The solute exchange at the sediment-water interface was calculated as follows:

$$
F_{x}=\frac{\left(C_{f}-C_{i}\right) \times V}{A \times t}
$$

where $F_{x}\left(\mu \mathrm{mol} \mathrm{m}{ }^{-2} \mathrm{~h}^{-1}\right)$ is the flux of the chemical species $x, C_{f}$ and $C_{i}\left(\mu \mathrm{mol} \mathrm{L}{ }^{-1}\right)$ are the final and initial concentrations of the chemical species $x$, respectively, $V(\mathrm{~L})$ is the water volume in a core, $A\left(\mathrm{~m}^{2}\right)$ is the surface area of the core sediments, and $t(\mathrm{~h})$ is the incubation time.

Dissolved $\mathrm{O}_{2}$ and $\mathrm{N}_{2}$ were measured as $\mathrm{O}_{2}$ :Ar and $\mathrm{N}_{2}$ :Ar ratios by membrane inlet mass spectrometry (MIMS, Bay Instruments, Maryland, USA) at Ferrara University, Ferrara, Italy [34]. Ratios were multiplied by theoretical Ar concentration at experimental water temperature and salinity. Nitrous oxide $\left(\mathrm{N}_{2} \mathrm{O}\right)$ concentrations were determined by headspace analysis on a Thermo Scientific Gas Bench-Precon-IRMS system at UC DAVIS the Stable Isotope Facility, California, USA. Dissolved $\mathrm{NH}_{4}{ }^{+}, \mathrm{NO}_{2}{ }^{-}$and $\mathrm{NO}_{3}{ }^{-}$were measured with a continuous flow analyzer $\left(\mathrm{San}^{++}\right.$, Skalar Analitical B.V., Breda, The Netherlands ) using standard colorimetric methods [35].

\subsection{Oxygen Consumption by Individual Chironomid Larvae}

In parallel to sediment core incubations, individual chironomid larvae were incubated in $0.22 \mu \mathrm{m}$ filtered water to assess the $\mathrm{O}_{2}$ consumption associated with the animals alone. Briefly, three individuals collected from the same location as above were placed in a Plexiglass chamber (total volume $227 \mathrm{~mL}$ ) which was partly filled $(41 \mathrm{~mL})$ with glass beads (diameter 200-300 $\mu \mathrm{m}$ ), and the rest filled with water $(186 \mathrm{~mL})$. For this experiment, five chambers with animals plus one chamber with filtered water only (control) were set up.

The chambers were sealed without including any air bubbles and were incubated for approximately $16 \mathrm{~h}$ in the dark at in situ temperature. A stirring magnet was placed in each chamber, allowing continuous water mixing during incubation. The concentrations of $\mathrm{O}_{2}$ in the water were monitored before and after incubation by a pre-calibrated Clark-type oxygen microelectrode (OX-50, Unisense A/S, Aarhus, Denmark). At the end of the incubation, larvae were recovered and weighed. In this experiment, the chironomid larvae wet weight was $0.030 \pm 0.003 \mathrm{~g}$ (mean \pm st. dev.). Oxygen consumption was then calculated as a function of animal wet weight ( $\mathrm{g} \mathrm{WW}$ ), according to Bonaglia et al. [36]. The $\mathrm{O}_{2}$ consumption rates in the experimental chambers with chironomid larvae were corrected for the minimal $\mathrm{O}_{2}$ consumption in the chamber with filtered water only.

\subsection{Nucleic Acid Extraction}

At the end of the incubation, sediments for molecular analyses were subsampled from the two randomly selected bioturbated cores (see Figure 1) by collecting approximately 1.5-2 g of subsurface (3-5 cm depth) anoxic sediment and sediments along the burrow wall with a sterile spatula. Anoxic sediments and sediment around burrows were clearly distinguishable by their color, with a light-brown-to-black transition from the oxidized burrow to the outer, chemically reduced sediment. Then, $0.3 \mathrm{~g}$ (wet weight) of sediment from each zone was homogenized and equally split for DNA and RNA extractions. Chironomid larvae $(n=6)$ were retrieved for molecular analyses from sediments 
and washed with sterile distilled water (three times). The three types of collected samples-(1) anoxic sediments, (2) oxidized burrow walls, and (3) chironomid larvae-were immediately processed for DNA and RNA extractions. Briefly, DNA was extracted and purified using the QIAamp Fast DNA Stool Mini Kit (Qiagen, Germantown, USA) following the manufacturer's protocol with an amended lysis temperature (temperature was increased to $90^{\circ} \mathrm{C}$ to improve bacterial cell rupture).

RNA was extracted with the RNA easy Mini Kit (Qiagen, Germantown, USA) applying additional incubation with lysozyme $(20 \mathrm{mg} / \mathrm{mL})$ and mutanolysin $\left(35 \mu \mathrm{L} / 1 \mathrm{~mL}\right.$ for $90 \mathrm{~min}$ at $\left.37^{\circ} \mathrm{C}\right)$. After incubation, $1 \mathrm{~mL}$ of Trizol was added and samples was subjected to four cycles of bead beating with glass beads (for $2 \mathrm{~min}$ ) and rested in the ice (for $3 \mathrm{~min}$ ) followed by incubation at room temperature (for $5 \mathrm{~min}$ ). Sediment and cell debris were pelleted by centrifugation at 12,000 rpm for $15 \mathrm{~min}$ at $4{ }^{\circ} \mathrm{C}$. The supernatant was transferred to a fresh tube and fixed with $0.2 \mathrm{~mL}$ of chloroform, mixed by inversion and left at room temperature for $15 \mathrm{~min}$ prior to centrifugation, as described above. The upper aqueous layer containing the RNA was transferred to a new sterile $1.5 \mathrm{~mL}$ tube, and RNA cleaning was performed using the RNAeasy Mini Kit (Qiagen, Germantown, USA) according to protocol instructions. The purified DNA and RNA was stored at $-80^{\circ} \mathrm{C}$.

\subsection{Synthesis of $c D N A$}

Extracted RNA were treated with TURBO DNase (Invitrogen, Carlsbad, USA) according to the manufacturer's instructions. To check whether the RNA sample was free of DNA, a control polymerase chain reaction (PCR) was carried out using universal bacterial primers of 16S rRNA [37]. PCR amplification was undertaken in a total volume of $22 \mu \mathrm{L}$ using $11 \mu \mathrm{L}$ of Platinum Green Hot Start 2X Master Mix (Invitrogen, Carlsbad, USA), $0.3 \mu \mathrm{M}$ of each primer, $1.25 \mu \mathrm{g} \mu \mathrm{L}^{-1}$ of bovine serum albumin (BSA) and $2 \mu \mathrm{L}$ of template. Thermocycling conditions were $95^{\circ} \mathrm{C}$ for $3 \mathrm{~min}$, followed by 30 cycles of $95^{\circ} \mathrm{C}$ for $30 \mathrm{~s}, 54^{\circ} \mathrm{C}$ for $30 \mathrm{~s}, 72^{\circ} \mathrm{C}$ for $45 \mathrm{~s}$, and a final extension of $72{ }^{\circ} \mathrm{C}$ for $10 \mathrm{~min}$.

Reverse transcription (RT) was performed with a SuperScript III Reverse Transcriptase (Invitrogen, Carlsbad, USA) following the manufacturer's instructions. Two negative controls lacking either reverse transcriptase or RNA were included. Control PCRs (same as above) were performed to confirm the transcription to complementary DNA (cDNA) and the negative controls using the product of the RT reaction as a template.

\subsection{Amplification and Sequencing of $16 S$ rRNA Gene and Bioinformatics}

Partial 16S rRNA gene sequences were amplified from extracted DNA using the primer pair Probio Uni/Probio Rev, targeting the V3 region of the 16S rRNA gene sequence [37]. The amplification of the $16 \mathrm{~S}$ rRNA gene was verified as previously described by Milani et al. [37]. High-throughput sequencing was performed at the DNA sequencing facility of GenProbio srl (Parma University, Parma, Italy) on an Illumina ${ }^{\mathrm{TM}}$ MiSeq according to the protocol previously reported in [37]. Metabarcoding reads recovered by paired-end sequencing were merged using the Illumina MiSeq analysis software under the default settings.

Following sequencing, the fastq files were processed using a custom script based on the QIIME software suite [38]. Paired-end read pairs were assembled to reconstruct the complete Probio Uni/Probio_Rev amplicons. Quality filtering retained sequences had a length between 140 and $400 \mathrm{bp}$ and a mean sequence quality score $>20$, while sequences with homopolymers $>7 \mathrm{bp}$ and mismatched primers were discarded. Operational taxonomic units (OTUs) were defined at $\geq 99 \%$ sequence homology using uclust [39], and OTUs with less than 10 sequences across datasets were filtered out. All reads were classified to the lowest possible taxonomic rank using QIIME [38] and a reference dataset from the SILVA 132 database [40].

\subsection{Quantitative PCR Analyses}

Quantitative polymerase chain reactions (qPCR) were used to quantify the abundance and activity of functional genes involved in N-cycling: (1) genes of haem-containing nitrite reductase (nirS), 
(2) Cu-containing nitrite reductase (nirK), (3) ammonia monooxygenase (amoA), and (4) cytochrome C nitrite reductase $(n r f A)$ (Table 1$)$.

Table 1. List of primers, strains and annealing temperatures used in this study. AOA-ammonia oxidizing archaea, $\mathrm{AOB}$ - ammonia oxidizing bacteria.

\begin{tabular}{|c|c|c|c|c|}
\hline Gene & Primer & Primer Sequence & Ann. Temp. & Reference Strain \\
\hline nirs & $\begin{array}{l}\text { F3nir } \\
\text { R4bcd }\end{array}$ & $\begin{array}{l}\text { SCCGCACCCGGGBCGYGG } \\
\text { CGTTGAAYTTRCCGGTSGG }\end{array}$ & $60^{\circ} \mathrm{C}$ & $\begin{array}{l}\text { Pseudomonas stutzeri } \\
\text { (DSM 4166) }\end{array}$ \\
\hline nirK & $\begin{array}{l}\mathrm{F} 1 \mathrm{aCu} \\
\mathrm{R} 3 \mathrm{Cu}\end{array}$ & $\begin{array}{l}\text { ATCATGGTSCTGCCGCG } \\
\text { GCCTCGATCAGRTTGTGGTT }\end{array}$ & $60^{\circ} \mathrm{C}$ & $\begin{array}{l}\text { Achromobcter sp. } \\
\text { (DSM 30128) }\end{array}$ \\
\hline AOA-amo $A$ & $\begin{array}{l}\text { AOA-amoA-f } \\
\text { AOA-amoA-r }\end{array}$ & $\begin{array}{l}\text { CTGAYTGGGCYTGGACATC } \\
\text { TTCTTCTTTGTTGCCCAGTA }\end{array}$ & $54-60^{\circ} \mathrm{C}$ & $\begin{array}{l}\text { Nitrosopumilus maritimus } \\
\text { (NCIMB 15022) }\end{array}$ \\
\hline AOB-amoA & $\begin{array}{l}\text { amoA-1F } \\
\text { amoA-2R }\end{array}$ & $\begin{array}{l}\text { GGGGHTTYTACTGGTGGT } \\
\text { CCCCTCKGSAAAGCCTTCTTC }\end{array}$ & $63^{\circ} \mathrm{C}$ & $\begin{array}{l}\text { Nitrosomonas europaea } \\
\quad \text { (DSM 28437) }\end{array}$ \\
\hline$n r f A$ & $\begin{array}{l}\text { nrfA-F2aw } \\
\text { nrfA-R1 }\end{array}$ & $\begin{array}{l}\text { CARTGYCAYGTBGARTA } \\
\text { TWNGGCATRTGRCARTC }\end{array}$ & $60^{\circ} \mathrm{C}$ & $\begin{array}{l}\text { Citrobacter freundii } \\
\text { (DSM 30039) }\end{array}$ \\
\hline
\end{tabular}

Genomic DNA from reference organisms was used to make standard curves and positive controls. Standard curves were constructed using PCR products of the nirS/K, $n r f A$ and $a m o A$ genes from the corresponding reference strains (Table 1). For this, the PCR products were purified with the commercial kit (PureLink PCR Purification Kit, Invitrogen, Carlsbad, USA) and their concentration was measured by Qubit 3.0 (Invitrogen, Carlsbad, USA). Obtained products were sequenced at BaseClear B.V (Leiden, The Netherlands) to confirm their identity. Then, serial dilutions were applied to verified products within the range of $10^{3}-10^{7}$ copies of a gene per reaction and used to calibrate the quantification of target genes in samples.

Quantitative PCR was performed with the StepOnePlus Real Time PCR system (ABI 7900 HT Sequence Detection System, PE Biosystems, Waltham, USA) using optical grade 96-well plates. The PCR reaction was run in the final volume of $20 \mu \mathrm{L}$ containing $10 \mu \mathrm{L}$ of SYBR Green master mix, $0.2 \mu \mathrm{M}$ of forward and reverse primers, $2 \mathrm{mM}$ of $\mathrm{MgCl}_{2}(25 \mathrm{mM})$ and $2 \mu \mathrm{L}$ of DNA sample (diluted 1/10). The thermocycling conditions were as follows: $50^{\circ} \mathrm{C}$ for $2 \mathrm{~min}$; initial denaturation at $94^{\circ} \mathrm{C}$ for $10 \mathrm{~min}$; 40 cycles at $94^{\circ} \mathrm{C}(1 \mathrm{~min}), 60^{\circ} \mathrm{C}(1 \mathrm{~min}), 72{ }^{\circ} \mathrm{C}(1.5 \mathrm{~min})$; and final elongation at $72{ }^{\circ} \mathrm{C}(5 \mathrm{~min})$. To assess the specificity of amplifications, a melting curve analysis was performed. Each sample was analyzed in triplicate. Triplicate no-template controls were included in each qPCR assay. The abundance and expression of target genes (DNA and RNA samples respectively) were recalculated to copies per g wet weight of a sample (sediment or chironomid larvae).

\subsection{Statistical Analysis}

The D3 JavaScript library [41] was used to visualize the taxonomic composition of metabarcoding data. Venn diagrams were generated using R package VennDiagram [42] to visualize the proportion of overlapping and unique OTUs within each dataset (anoxic sediments, burrow wall sediments, and chironomid larvae).

Quantitative data (benthic fluxes and abundance and expression of target genes) were visualized using boxplots. Non-parametric Kruskal-Wallis tests were applied to determine the significant difference in benthic net fluxes derived from experimental treatments (control and chironomid larvae microcosms) as well as the difference in the abundance and expression of target genes in anoxic sediments, burrow wall sediments and chironomid larvae. Where relevant, the post-hoc pairwise comparisons were performed using Dunn's test with Bonferroni alpha-correction implemented in the Pairwise Multiple Comparison of Mean Ranks package (PMCMRC, [43]). All analyses were performed in R v3 software [44]. 


\section{Results}

\subsection{Benthic Fluxes at the Sediment-Water Interface and Animal $\mathrm{O}_{2}$ Consumption}

The presence of chironomid larvae significantly increased benthic metabolism (Kruskal-Wallis test, $p<0.01$, for $\mathrm{O}_{2}$ and $\mathrm{N}_{2}$ ), reduced $\mathrm{NO}_{3}{ }^{-}$efflux and stimulated $\mathrm{NH}_{4}{ }^{+}$recycling (Figure 2). The uptake of $\mathrm{O}_{2}$ varied from -45.3 to $-3125 \mu \mathrm{mol} \mathrm{m} \mathrm{m}^{-2} \mathrm{~h}^{-1}$ with $72 \%$ higher respiration in the chironomid larvae treatment. The $\mathrm{O}_{2}$ uptake associated with chironomid larvae was $-269 \pm 21 \mu \mathrm{mol} \mathrm{g}^{-1} \mathrm{WW} \mathrm{d}^{-1}$ (range between -329 and $-216 \mu \mathrm{mol} \mathrm{g}^{-1} \mathrm{WW} \mathrm{d}^{-1}$ ). When extrapolated to a square meter of sediment containing 1800 individuals, this resulted in a chironomid-associated $\mathrm{O}_{2}$ uptake of $-598 \mu \mathrm{mol} \mathrm{m}^{-2} \mathrm{~h}^{-1}$.
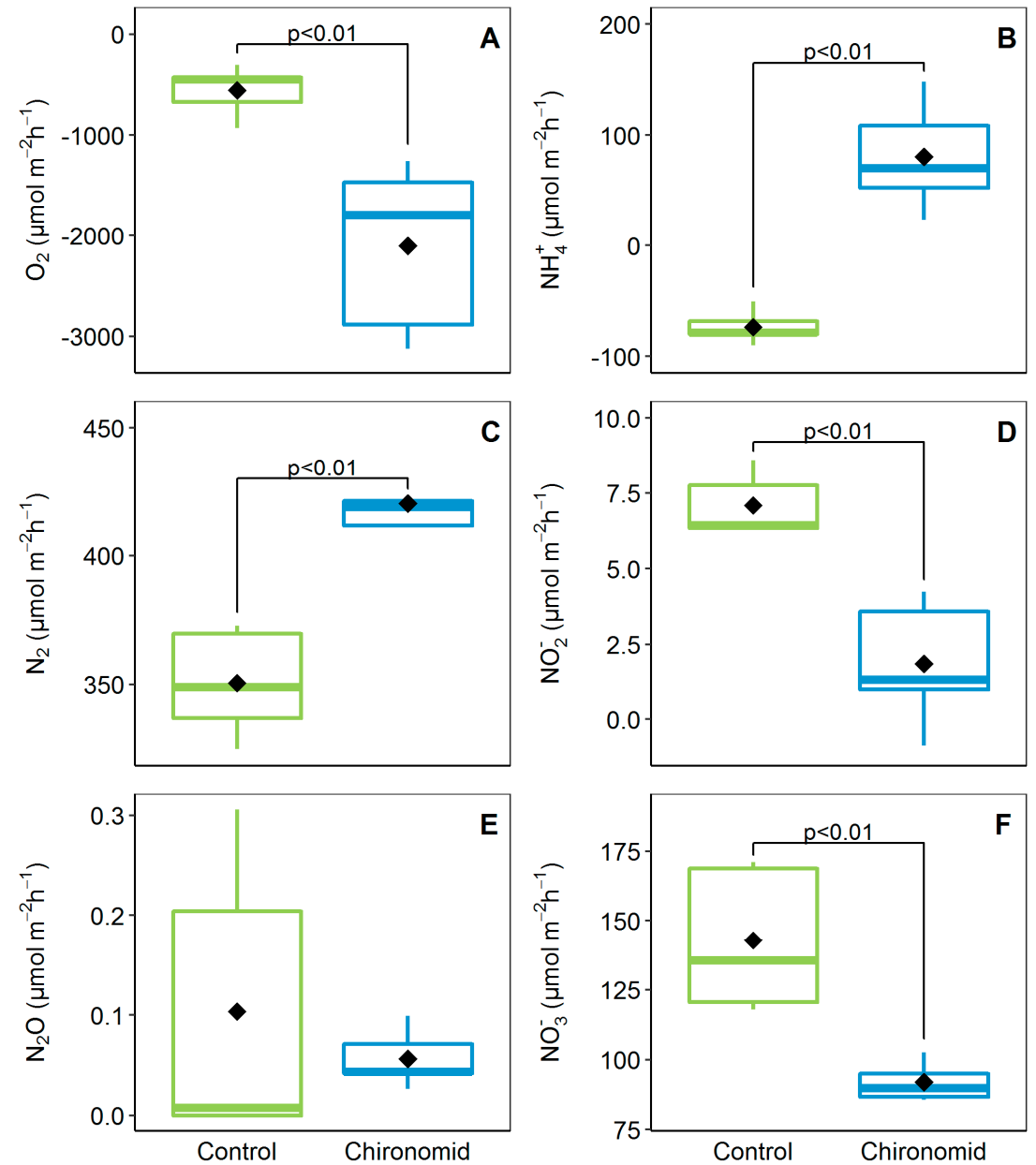

Figure 2. Benthic net fluxes of dissolved oxygen (A), ammonium (B), dinitrogen (C), nitrite (D), nitrous oxide $(\mathbf{E})$ and nitrate $(\mathbf{F})$ at the sediment-water interface measured in the control and the chironomid larvae microcosms. Each boxplot $(\mathrm{n}=5$ ) represents the data range (whiskers), upper and lower quartiles (edges), the median (horizontal line), and the mean (black diamond).

Similar to $\mathrm{O}_{2}$, net production of $\mathrm{N}_{2}$ was also higher in the chironomid treatment $\left(420.2 \pm 21.4 \mu \mathrm{mol} \mathrm{m}{ }^{-2} \mathrm{~h}^{-1}\right)$. We measured $\mathrm{N}_{2} \mathrm{O}$ efflux in both treatments, but due to high variability, the difference between the control and the chironomid treatment was not significant (Kruskal-Wallis test, $p>0.05$; Figure 2). The net flux of $\mathrm{N}_{2} \mathrm{O}$ being two orders of magnitude lower than $\mathrm{N}_{2}$ suggests that complete denitrification was the dominant process.

Chironomid larvae had a significant (Kruskal-Wallis test, $p<0.01$ ) effect on nutrient exchange at the sediment-water interface (Figure 2). In the presence of larvae, sediments shifted from a sink $\left(-73.5 \pm 14.9 \mu \mathrm{mol} \mathrm{m}^{-2} \mathrm{~h}^{-1}\right)$ to source of $\mathrm{NH}_{4}{ }^{+}\left(80.5 \pm 48.7 \mu \mathrm{mol} \mathrm{m}^{-2} \mathrm{~h}^{-1}\right)$. Conversely, the efflux of 
the oxidized form of inorganic $\mathrm{N}$ decreased when sediments were bioturbated by chironomid larvae. The net fluxes of $\mathrm{NO}_{2}{ }^{-}$and $\mathrm{NO}_{3}{ }^{-}$were 4 and 2 times lower in the chironomid treatment compared to the control.

\subsection{Bacterial Community Composition}

An overview of the bacterial community composition using $16 \mathrm{~S}$ rRNA metabarcoding revealed a prominent difference between sediment samples and chironomid larvae (Figure 3). Of the 35 bacterial phyla detected across all samples, Proteobacteria was the most dominant in sediment samples, followed by Nitrospirae and Chloroflexi. In chironomid larvae, the bacterial community was dominated by three phyla: Firmicutes (40.1\%), Proteobacteria (27.6\%) and Bacteroidetes (24.4\%). No Archea sequences were detected in the samples.

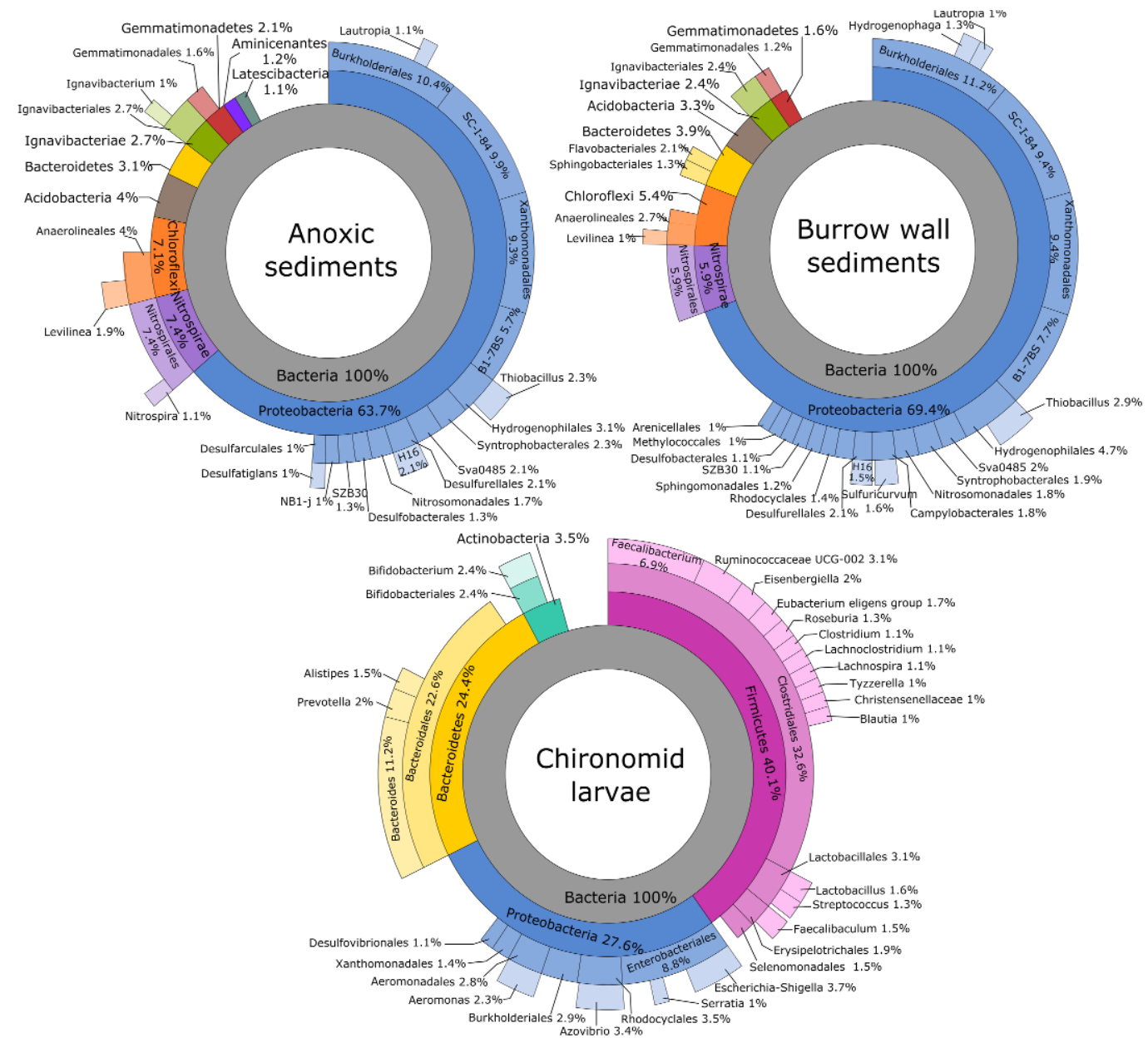

Figure 3. Overview of the bacterial community composition detected using the 16S rRNA marker gene in anoxic sediments, burrow wall sediments and chironomid larvae. The charts show the relative abundance of sequences at different taxonomic levels. To aid in visualization, taxa contributing $<0.1 \%$ are not shown. The inner circle demonstrates the percentage of taxa assigned at the highest level (Bacteria).

Out of 4841 OTUs detected across three samples, $17.8 \%$ were shared between sediments (anoxic sediment and burrow walls) and larvae (Figure 4). These OTUs represented 187 families and 24 phyla. Most of the shared OTUs present in chironomid larvae belonged to Firmicutes (41.4\%), Proteobacteria $(27.6 \%)$, and Bacteroidetes (24.4\%). The OTUs detected exclusively in chironomid samples (326 OTUs assigned to 14 families) were dominated by Tenericutes (59.3\% of reads), followed by Firmicutes 
(15.6\%), Saccharibacteria (10.4\%), Cyanobacteria and Elusimicrobia (3.8\% each), Actinobacteria (3.6\%) and Bacteroidetes (1.4\%).

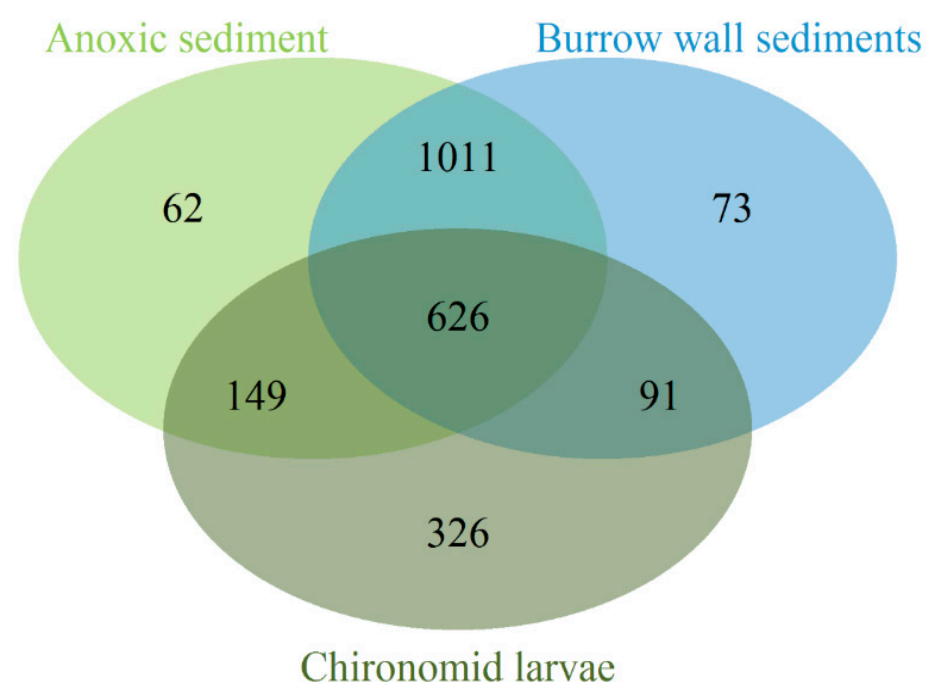

Figure 4. Venn diagram showing the numbers of unique and shared operational taxonomic units (OTUs) in anoxic sediment, burrow wall sediment and chironomid larvae samples (OTU numbers are indicated in the corresponding cross-sections of the diagram).

\subsection{Abunadance and Activity of Nitrifying and Denitrifying Genes}

Quantitative PCR assays used to quantify the abundance and transcriptional activity of the targeted functional genes associated with the oxidation of $\mathrm{NH}_{4}{ }^{+}$to $\mathrm{NO}_{2}{ }^{-}$(amoA) and its reduction to nitric oxide (NO; nirS/nirK) or to $\mathrm{NH}_{4}{ }^{+}(n r f A)$ showed that bacterial amoA genes were present in all samples, whereas archaeal amo $A$ genes were not detected. Significant differences $(p<0.05$, Kruskal-Wallis test followed by pairwise Dunn's test) were detected only for nirS and nrfA gene abundance between the anoxic sediment and chironomid larvae samples (Figure 5A,D). Gene transcripts of nitrite reductase genes nirS and $n r f A$ were detected in significantly lower copy numbers than their relative genes copy numbers ( $p<0.001$, Kruskal-Wallis test). Gene transcripts of bacterial amoA genes were detected and quantified from all types of samples at rather consistent rates, similar to DNA copy numbers detected for this gene (Figure 5C), whereas no nirK gene transcripts were detected in any type of samples (Figure 5B). 

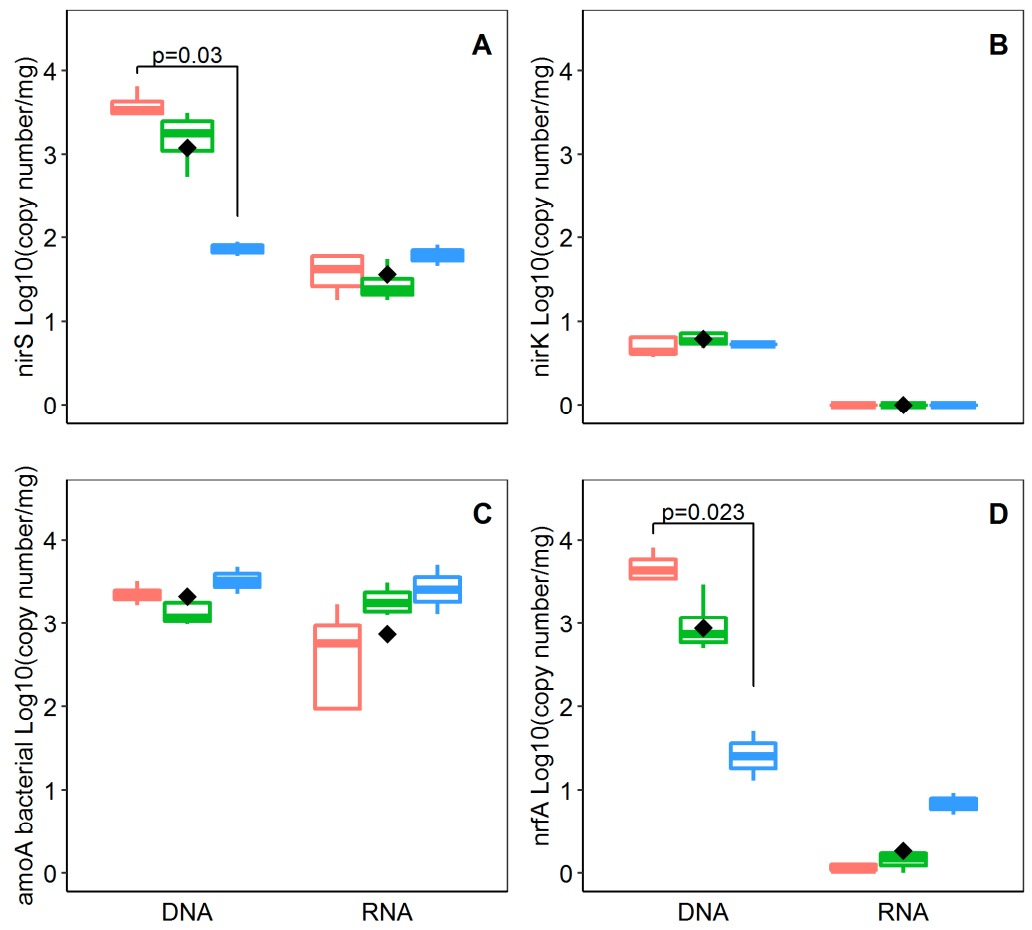

Treatment 户 Anoxic sediment

Figure 5. Abundance (DNA) and transcriptional activity (RNA) of the four analyzed target genes-nirS (A), nirK (B), amoA (C) and $\operatorname{nrfA}(\mathbf{D})$-assessed in the anoxic sediment, burrow wall sediment and chironomid larvae samples. Each boxplot represents the data range (whiskers), upper and lower quartiles (edges), median (horizontal line) and group mean (black diamond). The square brackets indicate significant pairwise difference between treatments (Kruskal-Wallis test followed by pairwise Dunn's test).

\section{Discussion}

Benthic macrofauna affect the distribution and quality of organic matter and the availability of electron acceptors by burrowing, ventilating and feeding, thus altering microbial communities and their metabolic activity [23,45]. In soft-sediment estuarine environments, it is generally expected that the cumulative effect of burrowing infauna on solute fluxes results in an overall increase of $\mathrm{NH}_{4}{ }^{+}$and $\mathrm{N}_{2}$ efflux and a decrease of $\mathrm{NO}_{3}{ }^{-}$efflux $[12,16,29]$. The present study aimed at a better understanding of how sediment-dwelling chironomid larvae facilitate solute transport, including electron acceptors $\left(\mathrm{O}_{2}\right.$ and $\left.\mathrm{NO}_{3}{ }^{-}\right)$, from the overlaying water column to the deep sediment, or vice versa. Furthermore, we were interested in how changes in solute transport in turn may stimulate microbial communities involved in nitrification and $\mathrm{NO}_{3}{ }^{-}$reduction processes within the sediment.

Higher $\mathrm{N}_{2}$ production in the presence of chironomid larvae confirms their stimulatory effect on denitrification, while $\mathrm{N}_{2} \mathrm{O}$ production did not change significantly between treatments and was considerably lower than $\mathrm{N}_{2}$ production. Our results are in line with those of a previous study indicating that with high $\mathrm{O}_{2}$ availability and low $\mathrm{NO}_{3}{ }^{-}$concentrations in the water, the overall $\mathrm{N}_{2} \mathrm{O}$ flux from both bioturbated and non-bioturbated sediments is minimal [36]. Stief et al. [46] described higher sedimentary $\mathrm{N}_{2} \mathrm{O}$ fluxes associated with the activity of C. plumosus, resulting from incomplete microbial denitrification in the larval gut. It was suggested that these $\mathrm{N}_{2} \mathrm{O}$ emissions were mainly constrained by the temperature and $\mathrm{NO}_{3}{ }^{-}$concentrations [47]. A recent study by Sun et al. [48] revealed that with the presence of nutritional food such as planktonic cyanobacteria, $\mathrm{N}_{2} \mathrm{O}$ production in the larval gut can significantly decrease. Cyanobacterial blooms, a common phenomenon in the Curonian Lagoon, may explain why we observed low $\mathrm{N}_{2} \mathrm{O}$ production in our study. Alternatively, a large portion of $\mathrm{N}_{2} \mathrm{O}$ possibly produced by the larvae [46,47] was likely consumed by sediment-denitrifying bacteria before 
reaching the overlying water. However, to confirm these hypotheses, additional measures of $\mathrm{N}_{2} \mathrm{O}$ and analyses of functional genes encoding $\mathrm{N}_{2} \mathrm{O}$ reduction to $\mathrm{N}_{2}$ (i.e., nos $\mathrm{Z}$ ) are needed.

As indicated by metabarcoding, the diversity of the bacterial community (numbers of OTUs) was slightly higher in sediment samples (both anoxic and burrow walls) compared to chironomid larvae. The latter had a peculiar composition and was dominated by bacterial groups (Firmicutes/Clostridiales) typical for animals' intestinal microbiota. These bacterial taxa during their fermentative growth, using reduced nicotinamide adenine dinucleotide (NADH) and $\mathrm{NO}_{2}{ }^{-}$or $\mathrm{NO}_{3}{ }^{-}$as substrates [49], can contribute to the production of $\mathrm{NH}_{4}{ }^{+}$[50]. However, some overlap was present in the composition of the microbial community associated with chironomid larvae and that of the surrounding sediments, which primarily comprised Proteobacteria. This abundant and diverse group includes microbial taxa capable of multiple $\mathrm{N}$ transformations, including anammox denitrification, DNRA and N-fixation [51].

Burrow ventilation, including the pumping of $\mathrm{NO}_{3}{ }^{-}$through the burrow, is considered one of the main mechanisms by which denitrification is stimulated in sediments reworked by chironomid larvae $[14,21,52,53]$. However, the degree of stimulation depends on $\mathrm{NO}_{3}{ }^{-}$concentration in the overlaying water [14]. In the Curonian Lagoon, $\mathrm{NO}_{3}{ }^{-}$concentration varies seasonally, and therefore the effect of chironomid larvae can differ among the seasons. The current study was carried out in summertime, when $\mathrm{NO}_{3}{ }^{-}$concentrations were generally low $\left(1.4 \mu \mathrm{mol} \mathrm{L}{ }^{-1}\right.$ on average). In a previous similar incubation experiment performed by Benelli et al. [12], $\mathrm{N}_{2}$ production was 2.6-fold higher than reported here, likely due to higher dissolved $\mathrm{NO}_{3}{ }^{-}$concentrations in spring $\left(109 \mu \mathrm{mol} \mathrm{L}{ }^{-1}\right)$.

Simple calculations, assuming that two moles of $\mathrm{NO}_{3}{ }^{-}$are required to produce one mole of $\mathrm{N}_{2}$, suggest that the increased uptake of $\mathrm{NO}_{3}{ }^{-}$in bioturbated sediment could only explain $41 \%$ of the measured $\mathrm{N}_{2}$ production. This indicates the potential relevance of coupled nitrification-denitrification in sediments bioturbated by chironomid larvae. By constructing burrows and pumping $\mathrm{O}_{2}$ through them, chironomid larvae create new niches for nitrifiers within the sediments $[6,10,15]$. Since bacteria require $\mathrm{O}_{2}$ for $\mathrm{NH}_{4}{ }^{+}$oxidation, respiration $\left(\mathrm{O}_{2}\right.$ uptake) is expected to increase alongside nitrification. In the present study, chironomid larvae stimulated respiration by 3.8-fold in comparison to the controls-a stronger effect than that reported earlier by Benelli et al. [12] and by Svensson and Leonardsson [14]. Our extrapolations showed that approximately $28 \%$ of the total $\mathrm{O}_{2}$ consumption was taken up directly by chironomid larvae and $24 \%$ by the sediment surface, which leaves approximately $48 \%$ of the $\mathrm{O}_{2}$ consumption related to newly oxidized burrow structures (for example, see the substantial volume of oxidized sediment around larvae borrows in Figure 6). Our estimated 28\% of oxygen consumption by larvae is consistent with that reported by Svensson and Leonardsson [14].
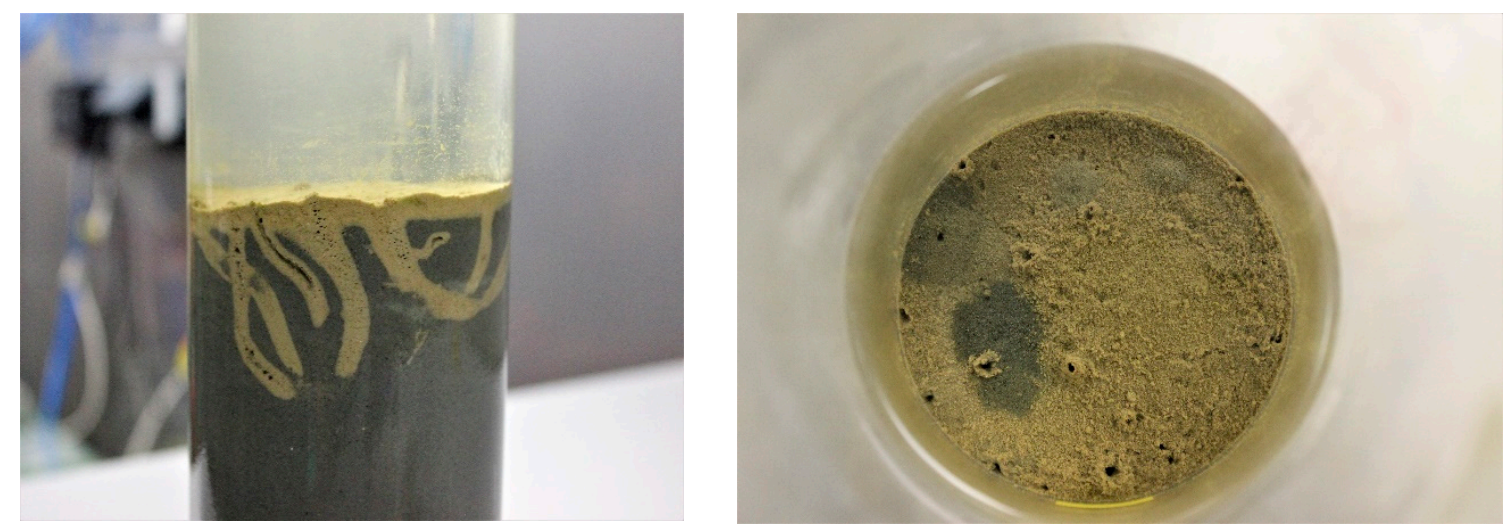

Figure 6. The bioturbation effects of chironomid larvae, evident in sharp contrast between the light-brown oxidized surface and burrow sediment, and black chemically reduced subsurface sediment (photo by A. Mačiūtè).

However, the degree of stimulation of nitrifiers might be species-specific, as chironomid larvae vary in size, bioturbation mode or grazing pressure on bacteria. Small chironomid species such 
as Chironomus riparius construct burrows in the upper $1 \mathrm{~cm}$ layer where they directly (grazing) or indirectly (burrow ventilation) affect nitrification processes [15]. Larger species, such as C. plumosus or Chironomus sp., can construct burrows down to $10 \mathrm{~cm}$, significantly extending the niche for nitrifiers and consequently enhancing $\mathrm{N}$-cycling rates [21,54]. Therefore, our findings cannot be generalized for all chironomid species or other macrobenthic invertebrates.

Despite denitrification increasing with the presence of chironomid larvae, its efficiency, expressed as the ratio between the $\mathrm{N}_{2}$ flux and the sum of $\mathrm{N}_{2}+$ DIN fluxes, decreased by $20 \%$ in bioturbated sediments (from $84 \%$ to $65 \%$ ). The increased $\mathrm{NH}_{4}{ }^{+}$efflux in bioturbated sediments can explain this pattern. Deep-burrowing chironomids are able to increase the upward flux of $\mathrm{NH}_{4}{ }^{+}$from deeper layers (where its pool is considerably higher due to the limited oxidation through nitrification) [12,21,55]. The assumed main source of $\mathrm{NH}_{4}{ }^{+}$in deep sediment pore water is the mineralization of organic matter, as the excretion of $\mathrm{NH}_{4}{ }^{+}$by chironomid larvae rarely exceeds $20 \%$ of the immobilized ammonium pool $[11,14]$.

It has never been questioned whether $\mathrm{NH}_{4}{ }^{+}$excretion by chironomid larvae is solely a physiological process or if it could also be attributed to larvae-bacteria associations (e.g., gut microbiomes). Poulsen et al. [29] showed that the C. plumosus gut can host $\mathrm{NO}_{3}{ }^{-}$reducing microbes, but their targeted functional gene (nar) did not allow them to distinguish between nitrite denitrifiers or ammonifiers. Here, we show that the larvae-associated microbial community exhibited transcriptional activity of the $n r f A$ gene, which encodes DNRA. This process is strictly anaerobic and may thus potentially occur in the anoxic larvae gut [28]. Therefore, active $\mathrm{NO}_{3}{ }^{-}$-respiring intestinal bacteria of infauna can act as an alternative source of $\mathrm{NH}_{4}{ }^{+}$in soft-bottom environment.

This was also supported by our functional gene quantification that showed a higher potential for denitrification and DNRA in chironomid larvae rather than in the surrounding sediments. Although nirS and nrfA genes, encoding $\mathrm{NO}_{2}{ }^{-}$reduction to $\mathrm{NO}$ and to $\mathrm{NH}_{4}{ }^{+}$, respectively, were abundant in anoxic sediment and on the burrow walls, their expression was comparatively low. This indicates that chironomid larvae can provide favourable conditions for bacteria harbouring these genes, facilitating their activity. The expression of nirS and $n r f A$ genes can be affected by a number of environmental variables, including $\mathrm{O}_{2}$, temperature, and organic matter availability [56]. This notwithstanding, there is numerous evidence that ingested bacteria can remain active in the larvae gut and carry out $\mathrm{NO}_{3}{ }^{-}$reduction $[29,46]$. In addition, an anoxic gut environment might stimulate $\mathrm{NO}_{3}{ }^{-}$reduction by facultative aerobic bacteria [28,29]. A higher nirS gene copy number points at denitrification as the dominating pathway of $\mathrm{NO}_{3}{ }^{-}$reduction. The differences in the expression of nirS or $n r f A$ genes can be explained by different bacterial affinity to labile carbon, $\mathrm{NO}_{3}{ }^{-}$and sulphide concentration, and temperature $[57,58]$.

The quantification of $a m o A$, which encodes the ammonia monooxygenase for the oxidation of $\mathrm{NH}_{4}{ }^{+}$ to $\mathrm{NO}_{2}{ }^{-}$, revealed that its abundance and activity was primarily associated with ammonium oxidizing bacteria (AOB) in burrows and chironomid larvae. This is likely due to the simultaneous availability of $\mathrm{O}_{2}$ and $\mathrm{NH}_{4}{ }^{+}$, which is favourable for AOB. Surprisingly, relatively high copy numbers of amo $A$ were associated with the larval body. Since nitrification is an aerobic process and is unexpected in the anoxic environment of larvae gut and intestine, the active nitrifying bacteria might have been located on the external biofilm of the chironomid body, thus having direct access to $\mathrm{NH}_{4}{ }^{+}$and $\mathrm{O}_{2}$-enriched pore water, within the larvae-ventilated burrow.

\section{Conclusions}

The present study confirms that tube-dwelling invertebrates such as C. plumosus may have a considerable influence on N-cycling in estuarine sediments. Combining biogeochemical (flux measurements) and molecular (metabarcoding, functional gene analysis) approaches allowed the precise identification of $\mathrm{N}$ transformation hot-spots (burrow lining, macrofauna gut) and the quantification of their contribution to in-sediment $\mathrm{N}$-cycling processes. Chironomid larvae stimulated nitrification, denitrification and $\mathrm{NH}_{4}{ }^{+}$production, while increased $\mathrm{N}$ recycling reduced denitrification efficiency. 
Chironomid larvae produced visible, direct effects on the volume of oxidized sediments, creating new suboxic niches via burrowing and ventilation. They harboured a unique and active array of bacteria compared to those found in the surrounding environment. Interestingly, active functional genes involved in contrasting processes such as nitrification and $\mathrm{NO}_{3}{ }^{-}$reduction were detected both in sediments and the larvae microbiome, suggesting the co-occurrence of adjacent oxic and anoxic niches also within the larvae. Our study suggests that overlooked invertebrate-bacteria associations could be a significant component of $\mathrm{N}$-cycling in benthic environments. Future studies should further scrutinize microbially mediated $\mathrm{N}$ processes in isolated macrofauna to partition nitrification and denitrification processes associated with intimate animal-bacteria interactions.

Author Contributions: Conceptualization, M.Z.; methodology, A.S., M.B., I.V.-L.; formal analysis, A.Z.; investigation, A.S., M.B., S.B., I.V.-L., J.P.; visualization, A.Z.; funding acquisition, M.Z.; data curation, T.P.; writing—original draft preparation, A.S., M.Z.; writing—review and editing, M.B., S.B., U.C., U.M., J.P., T.P., A.Z.

Funding: This research is supported by the "Invertebrate-Bacterial Associations as Hotpots of Benthic Nitrogen Cycling in Estuarine Ecosystems (INBALANCE)" project, which is funded by the European Social Fund according to the activity "Improvement of researchers qualification by implementing world-class R\&D projects of Measure", grant No. 09.3.3-LMT-K-712-01-0069. T.B. was supported by the Doctorate Study Programme in Ecology and Environmental Sciences, Klaipèda University.

Acknowledgments: We gratefully thank Adele Mačiūte and Andrius Šaulys for their assistance in field sampling and laboratory analysis.

Conflicts of Interest: The authors declare no conflict of interest.

\section{References}

1. Asmala, E.; Carstensen, J.; Conley, D.J.; Slomp, C.P.; Stadmark, J.; Voss, M. Efficiency of the coastal filter: Nitrogen and phosphorus removal in the Baltic Sea. Limnol. Oceanogr. 2017, 62, S222-S238. [CrossRef]

2. Zilius, M.; Vybernaite-Lubiene, I.; Vaiciute, D.; Petkuviene, J.; Zemlys, P.; Liskow, I.; Voss, M.; Bartoli, M.; Bukaveckas, P.A. The influence of cyanobacteria blooms on the attenuation of nitrogen throughputs in a Baltic coastal lagoon. Biogeochemistry 2018, 141, 143-165. [CrossRef]

3. Bianchi, T.S. Biogeochemistry of Estuaries; Oxford University Press: New York, NY, USA, 2007.

4. Brinson, M.M.; Christian, R.R.; Blum, L.K. Multiple states in the sea-level induced transition from terrestrial forest to estuary. Estuaries 1995, 18, 648-659. [CrossRef]

5. Kristensen, E. Organic matter diagenesis at the oxic/anoxic interface in coastal marine sediments, with emphasis on the role of burrowing animals. Hydrobiologia 2000, 426, 1-24. [CrossRef]

6. Mermillod-Blondin, F.; Rosenberg, R.; François-Carcaillet, F.; Norling, K.; Mauclaire, L. Influence of bioturbation by three benthic infaunal species on microbial communities and biogeochemical processes in marine sediment. Aquat. Microb. Ecol. 2004, 36, 271-284. [CrossRef]

7. Magri, M.; Benelli, S.; Bondavalli, C.; Bartoli, M.; Christian, R.R.; Bodini, A. Benthic N pathways in illuminated and bioturbated sediments studied with network analysis. Limnol. Oceanogr. 2018, 63, S68-S84. [CrossRef]

8. An, S.; Gardner, W.S. Dissimilatory nitrate reduction to ammonium (DNRA) as a nitrogen link, versus denitrification as a sink in a shallow estuary (Laguna Madre/Baffin Bay, Texas). Mar. Ecol. Prog. Ser. 2002, 237, 41-50. [CrossRef]

9. Bonaglia, S.; Deutsch, B.; Bartoli, M.; Marchant, H.K.; Brüchert, V. Seasonal oxygen, nitrogen and phosphorus benthic cycling along an impacted Baltic Sea estuary: Regulation and spatial patterns. Biogeochemistry 2014, 119, 139-160. [CrossRef]

10. Vybernaite-Lubiene, I.; Zilius, M.; Saltyte-Vaisiauske, L.; Bartoli, M. Recent trends (2012-2016) of N, Si, and P export from the Nemunas River Watershed: Loads, unbalanced stoichiometry, and threats for downstream aquatic ecosystems. Water 2018, 10, 1178. [CrossRef]

11. Carstensen, J.; Conley, D.J.; Bonsdorff, E.; Gustafsson, B.G.; Hietanen, S.; Janas, U.; Jilbert, T.; Maximov, A.; Norkko, A.; Norkko, J.; et al. Hypoxia in the Baltic Sea: Biogeochemical cycles, benthic fauna, and management. Ambio 2014, 43, 26-36. [CrossRef]

12. Benelli, S.; Bartoli, M.; Zilius, M.; Vybernaite-Lubiene, I.; Ruginis, T.; Petkuviene, J.; Fano, E.A. Microphytobenthos and chironomid larvae attenuate nutrient recycling in shallow-water sediments. Freshw. Biol. 2018, 63, 187-201. [CrossRef] 
13. Kristensen, E.; Penha-Lopes, G.; Delefosse, M.; Valdemarsen, T.; Quintana, C.O.; Banta, G.T. What is bioturbation? The need for a precise definition for fauna in aquatic sciences. Mar. Ecol. Prog. Ser. 2012, 446, 285-302. [CrossRef]

14. Svensson, J.E.; Leonardson, L.G. Effects of bioturbation by tube-dwelling chironomid larvae on oxygen uptake and denitrification in eutrophic lake sediments. Freshw. Biol. 1996, 35, 289-300. [CrossRef]

15. Stief, P.; Beer, D.D. Probing the microenvironment of freshwater sediment macrofauna: Implications of deposit-feeding and bioirrigation for nitrogen cycling. Limnol. Oceanogr. 2006, 51, 2538-2548. [CrossRef]

16. Bonaglia, S.; Nascimento, F.A.; Bartoli, M.; Klawonn, I.; Brüchert, V. Meiofauna increases bacterial denitrification in marine sediments. Nat. Commun. 2014, 5, 5133. [CrossRef] [PubMed]

17. Laverock, B.; Tait, K.; Gilbert, J.A.; Osborn, A.M.; Widdicombe, S. Impacts of bioturbation on temporal variation in bacterial and archaeal nitrogen-cycling gene abundance in coastal sediments. Environ. Microbiol. Rep. 2014, 6, 113-121. [CrossRef] [PubMed]

18. Foshtomi, M.Y.; Braeckman, U.; Derycke, S.; Sapp, M.; Van Gansbeke, D.; Sabbe, K.; Willems, A.; Vincx, M.; Vanaverbeke, J. The link between microbial diversity and nitrogen cycling in marine sediments is modulated by macrofaunal bioturbation. PLoS ONE 2015, 10, e0130116.

19. Welsh, D.T.; Nizzoli, D.; Fano, E.A.; Viaroli, P. Direct contribution of clams (Ruditapes philippinarum) to benthic fluxes, nitrification, denitrification and nitrous oxide emission in a farmed sediment. Estuar. Coast. Shelf Sci. 2015, 154, 84-93. [CrossRef]

20. Foshtomi, M.Y.; Leliaert, F.; Derycke, S.; Willems, A.; Vincx, M.; Vanaverbeke, J. The effect of bio-irrigation by the polychaete Lanice conchilega on active denitrifiers: Distribution, diversity and composition of nosZ gene. PLOS ONE 2018, 13, e0192391.

21. Moraes, P.C.; Zilius, M.; Benelli, S.; Bartoli, M. Nitrification and denitrification in estuarine sediments with tube-dwelling benthic animals. Hydrobiologia 2018, 819, 217-230. [CrossRef]

22. Murphy, A.E.; Kolkmeyer, R.; Song, B.; Anderson, I.C.; Bowen, J. Bioreactivity and Microbiome of Biodeposits from Filter-Feeding Bivalves. Microb. Ecol. 2019, 77, 343-357. [CrossRef]

23. Stief, P. Stimulation of microbial nitrogen cycling in aquatic ecosystems by benthic macrofauna: Mechanisms and environmental implications. Biogeosciences 2013, 10, 7829-7846. [CrossRef]

24. Laverock, B.; Gilbert, J.A.; Tait, K.; Osborn, A.M.; Widdicombe, S. Bioturbation: Impact on the marine nitrogen cycle. Biochem. Soc. Trans. 2011, 39, 315-320. [CrossRef]

25. Gilbertson, W.W.; Solan, M.; Prosser, J.I. Differential effects of microorganism-invertebrate interactions on benthic nitrogen cycling. FEMS Microbiol. Ecol. 2012, 82, 11-22. [CrossRef]

26. Bartoli, M.; Nizzoli, D.; Viaroli, P. Microphytobenthos activity and fluxes at the sediment-water interface: Interactions and spatial variability. Aquat. Ecol. 2003, 37, 341-349. [CrossRef]

27. Moulton, O.M.; Altabet, M.A.; Beman, J.M.; Deegan, L.A.; Lloret, J.; Lyons, M.K.; Nelson, J.A.; Pfister, C.A. Microbial associations with macrobiota in coastal ecosystems: Patterns and implications for nitrogen cycling. Front. Ecol. Environ. 2016, 14, 200-208. [CrossRef]

28. Stief, P.; Eller, G. The gut microenvironment of sediment-dwelling Chironomus plumosus larvae as characterised with $\mathrm{O}_{2}, \mathrm{pH}$, and redox microsensors. J. Comp. Physiol. B 2006, 176, 673-683. [CrossRef]

29. Poulsen, M.; Kofoed, M.V.; Larsen, L.H.; Schramm, A.; Stief, P. Chironomus plumosus larvae increase fluxes of denitrification products and diversity of nitrate-reducing bacteria in freshwater sediment. Syst. Appl. Microbiol. 2014, 37, 51-59. [CrossRef]

30. Petersen, J.M.; Kemper, A.; Gruber-Vodicka, H.; Cardini, U.; van der Geest, M.; Kleiner, M.; Silvia Bulgheresi, S.; Mußmann, M.; Herbold, C.; Seah, B.K.B.; et al. Chemosynthetic symbionts of marine invertebrate animals are capable of nitrogen fixation. Nat. Microbiol. 2016, 2, 16196. [CrossRef]

31. Hölker, F.; Vanni, M.J.; Kuiper, J.J.; Meile, C.; Grossart, H.P.; Stief, P.; Adrian, R.; Lorke, A.; Dellwig, O.; Brand, A.; et al. Tube-dwelling invertebrates: Tiny ecosystem engineers have large effects in lake ecosystems. Ecol. Monogr. 2015, 85, 333-351. [CrossRef]

32. Stocum, E.T.; Plante, C.J. The eect of artificial defaunation on bacterial assemblages of intertidal sediments. J. Exp. Mar. Biol. Ecol. 2006, 337, 147-158. [CrossRef]

33. Dalsgaard, T.; Nielsen, L.P.; Brotas, V.; Viaroli, P.; Underwood, G.; Nedwell, D.; Dong, L.D.; Sundbäck, K.; Rysgaard, S.; Miles, A.; et al. Protocol Handbook for NICE-Nitrogen Cycling in Estuaries: A Project under the EU Research Programme: Marine Science and Technology (MAST III); Ministry of Environment and Energy National Environmental Research Institute: Silkeborg, Denmark, 2000; pp. 1-62. 
34. Kana, T.M.; Darkangelo, C.; Hunt, M.D.; Oldham, J.B.; Bennett, G.E.; Cornwell, J.C. Membrane inlet mass spectrometer for rapid high-precision determination of $\mathrm{N}_{2}, \mathrm{O}_{2}$, and $\mathrm{Ar}$ in environmental water samples. Anal. Chem. 1994, 66, 4166-4170. [CrossRef]

35. Grassshoff, K. Determination of nitrate. In Methods of Seawater Analysis; Grassoff, K., Ehrhardt, M., Kremling, K., Eds.; Verlag Chemie: Weinheimm, Germany, 1982; p. 143.

36. Bonaglia, S.; Brüchert, V.; Callac, N.; Vicenzi, A.; Fru, E.C.; Nascimento, F.J.A. Methane fluxes from coastal sediments are enhanced by macrofauna. Sci. Rep. 2017, 7, 13145. [CrossRef]

37. Milani, C.; Hevia, A.; Foroni, E.; Duranti, S.; Turroni, F.; Lugli, G.A.; Sanchez, B.; Martín, R.; Gueimonde, M.; van Sinderen, D.; et al. Assessing the fecal microbiota: An optimized ion torrent 16S rRNA gene-based analysis protocol. PLoS ONE 2013, 8, e68739. [CrossRef]

38. Caporaso, J.G.; Kuczynski, J.; Stombaugh, J.; Bittinger, K.; Bushman, F.D.; Costello, E.K.; Fierer, N.; Peña, A.G.; Goodrich, J.K.; Gordon, J.I.; et al. QIIME allows analysis of high-throughput community sequencing data. Nat. Methods 2010, 7, 335-336. [CrossRef]

39. Edgar, R.C. Search and clustering orders of magnitude faster than BLAST. Bioinformatics 2010, 26, $2460-2461$. [CrossRef]

40. Quast, C.; Pruesse, E.; Yilmaz, P.; Gerken, J.; Schweer, T.; Yarza, P.; Peplies, J.; Glöckner, F.O. The SILVA ribosomal RNA gene database project: Improved data processing and web-based tools. Nucleic Acids Res. 2012, 41, D590-D596. [CrossRef]

41. Data-Driven Documents. Available online: https://d3js.org (accessed on 22 July 2019).

42. Chen, H.; Boutros, P.C. VennDiagram: A package for the generation of highly-customizable Venn and Euler diagrams in R. BMC Bioinform. 2011, 12, 35. [CrossRef]

43. Pohlert, T. The Pairwise Multiple Comparison of Mean Ranks Package (PMCMR); R Package, 2014; p. 27.

44. R-Project. R: A Language and Environment for Statistical Computing [Online]. R Foundation for Statistical Computing: Vienna, Austria. 2014. Available online: http://www.R-project.org (accessed on 22 July 2019).

45. Welsh, D.T. It's a dirty job but someone has to do it: The role of marine benthic macrofauna in organic matter turnover and nutrient recycling to the water column. Chem. Ecol. 2003, 19, 321-342. [CrossRef]

46. Stief, P.; Poulsen, M.; Nielsen, L.P.; Brix, H.; Schramm, A. Nitrous oxide emission by aquatic macrofauna. Proc. Natl. Acad. Sci. USA 2009, 106, 4296-4300. [CrossRef]

47. Stief, P.; Schramm, A. Regulation of nitrous oxide emission associated with benthic invertebrates. Freshw. Biol. 2010, 55, 1647-1657. [CrossRef]

48. Sun, X.; Hu, Z.; Jia, W.; Duan, C.; Yang, L. Decaying cyanobacteria decrease $\mathrm{N}_{2} \mathrm{O}$ emissions related to diversity of intestinal denitrifiers of Chironomus plumosus. J. Limnol. 2015, 74. [CrossRef]

49. Cabello, P.; Roldán, M.D.; Castillo, F.; Moreno-Vivián, C. Nitrogen cycle. In Encyclopaedia of Microbiology, 3rd ed.; Schaechter, M., Ed.; Academic Press: London, UK, 2009.

50. Baggs, E.; Phillipot, L. Nitrous oxide production in the terrestrial environment. In Nitrogen Cycling in Bacteria: Molecular Analysis; Moir, J.W.B., Ed.; Caister Academic Press: Norfolk, UK, 2011.

51. Rasigraf, O.; Schmitt, J.; Jetten, M.S.M.; Lüke, C. Metagenomic potential for and diversity of N-cycle driving microorganisms in the Bothnian Sea sediment. Microbiol. Open. 2017, 6, e475. [CrossRef]

52. Svensson, J.M. Influence of Chironomus plumosus larvae on ammonium flux and denitrification (measured by the acetylene blockage- and the isotope pairing-technique) in eutrophic lake sediment. Hydrobiologia 1997, 346, 157-168. [CrossRef]

53. Pelegrí, S.P.; Blackburn, T.H. Nitrogen cycling in lake sediments bioturbated by Chironomus plumosus larvae, under different degrees of oxygenation. Hydrobiologia 1996, 325, 231-238. [CrossRef]

54. Xing, X.; Liu, L.; Yan, W.; Wu, T.; Zhao, L.; Wang, X. Bioturbation effects of Chironomid larvae on nitrogen release and ammonia-oxidizing bacteria abundance in sediments. Water 2018, 10, 512. [CrossRef]

55. Nogaro, G.; Mermillod-Blondin, F.; Montuelle, B.; Boisson, J.C.; Gibert, J. Chironomid larvae stimulate biogeochemical and microbial processes in a riverbed covered with fine sediment. Aquat. Sci. 2008, 70, 156-168. [CrossRef]

56. Song, B.; Lisa, J.A.; Tobias, C.R. Linking DNRA community structure and activity in a shallow lagoonal estuarine system. Front. Microbiol. 2014, 5, 460. [CrossRef] 
57. Herbert, R.A. Nitrogen cycling in coastal marine ecosystems. FEMS Microbiol. Rev. 1999, 23, 563-590. [CrossRef]

58. Burgin, A.J.; Hamilton, S.K. Have we overemphasized the role of denitrification in aquatic ecosystems? A review of nitrate removal pathways. Front. Ecol. Environ. 2007, 5, 89-96. [CrossRef]

(C) 2019 by the authors. Licensee MDPI, Basel, Switzerland. This article is an open access article distributed under the terms and conditions of the Creative Commons Attribution (CC BY) license (http://creativecommons.org/licenses/by/4.0/). 